\title{
Organization of the Chloroplast Ribosomal RNA Genes of Euglena gracilis bacillaris
}

\author{
Robert B. Helling ${ }^{1}$, M. Raafat El-Gewely ${ }^{1}$, Margaret I. Lomax ${ }^{1}$, James E. Baumgartner ${ }^{1}$, \\ Steven D. Schwartzbach ${ }^{2}$, and W. Edgar Barnett ${ }^{3}$ \\ ${ }^{1}$ Division of Biological Sciences, University of Michigan, Ann Arbor, Michigan 48109, USA \\ 2 School of Life Sciences, University of Nebraska, Lincoln, Nebraska 68588, USA \\ ${ }^{3}$ Division of Biology, Oak Ridge National Laboratory, Oak Ridge, Tennessee 37830, USA
}

Summary. The order of eight of the 29 endonuclease EcoRI-generated fragments of chloroplast DNA was determined. Three sets of rRNA genes aligned sequentially in the same orientation form part of this region. The repeated sets differ in the length and sequence of the spacers among themselves and with the rRNA genes of E. gracilis strain $Z$.

\section{Introduction}

A primary goal of cell biology is to understand the evolution and biogenesis of organelles and how organelles interact with the cytoplasm and nucleus. A direct and necessary approach to achieving this goal is to determine the structures, organization, and functions of the genes in an organelle. We have chosen to do this with the chloroplast genes of the unicellular alga Euglena gracilis.

E. gracilis chloroplasts contain circular DNA molecules about 138 kilobase pairs $(\mathrm{kb})$ in length (Manning and Richards, 1972; Slavik and Hershberger, 1975). About $17 \mathrm{~kb}$ of DNA is required to code for the three sets of ribosomal RNA (rRNA) genes (Rawson et al., 1978; Gray and Hallick, 1978; this paper), and another $2 \mathrm{~kb}$ codes for the approximately 26 transfer RNA (tRNA) genes (Schwartzbach, Hecker and Barnett, 1976; McCrea and Hershberger, 1976; Gruol and Haselkorn, 1976). This leaves enough DNA to code for perhaps 120 average polypeptides, assuming that all remaining DNA is transcriptionally active. The catalytic subunit of the $\mathrm{CO}_{2}$-fixing enzyme, ribulosebisphosphate carboxylase, is coded by chloroplast DNA but chloroplast genes for almost

For offprints contact: R.B. Helling no other proteins have been identified. However Rawson has found that at least $85 \mathrm{~kb}$ of chloroplast DNA form transcripts during some stage of growth (Rawson and Boerma, 1976).

We have cloned a large part of the $E$. gracilis chloroplast DNA in plasmids of Escherichia coli (Lomax et al., 1977; this paper). The cloned DNA segments were generated by a variety of restriction endonucleases. We have used these clones to determine the order of a set of endonuclease EcoRI - generated chloroplast DNA fragments, and to derive a detailed map of the rRNA genes included in this set of fragments.

\section{Materials and Methods}

Materials. Plasmids were maintained in $\mathrm{RH} 201\left(\mathrm{~F}^{+}\right.$thr leu thi lac $Y$ tonA supE hss) or its $\mathrm{thr}^{+} \mathrm{leu}^{+}$derivative RH202 (Adams et al., 1979). Cloning of E. gracilis bacillaris chloroplast DNA was carried out as described (Lomax et al., 1977; Helling and Lomax, 1978). All constructed plasmids (Table 1) were purified by transformation prior to use. Plasmid and chloroplast DNA preparations have been described (Lomax et al., 1977).

Restriction Endonucleases. EcoRI, BamHI, and SaICI were prepared by us. Other restriction enzymes (Kpn I, Pst I, and Xho

Table 1. Plasmids containing segments of chloroplast DNA

\begin{tabular}{llll}
\hline Plasmid & $\begin{array}{l}\text { Size of cloned } \\
\text { fragments }(\mathrm{kb})\end{array}$ & $\begin{array}{l}\text { Parent } \\
\text { plasmid }\end{array}$ & $\begin{array}{l}\text { Chloroplast } \\
\text { DNA segment }\end{array}$ \\
\hline pMIL12 & 2.48 & pSF2124 & Eco R \\
pMIL17 & 4.91 & pSF2124 & Eco S, U, 2A \\
pMIL19 & 3.2 & pSF2124 & Eco M \\
PRBHO21 & 4.4 & pBR322 & Sal C \\
pRBHO22 & 5.25 & pBR322 & Bam F \\
pRBHO23 & 5.68 & pBR322 & Bam E \\
pRBHO26 & 5.68 & pBR322 & Bam E \\
\hline
\end{tabular}


I) were purchased from New England Biolabs and from Bethesda Research Laboratories. T4 ligase was purchased from Miles Laboratories and from Bethesda Research Laboratories. DNA polymerase I was purchased from Boehringer Mannheim and from New England Biolabs. E. coli RNA polymerase was generously provided by $D$. Brutlag. The restriction endonucleases and their DNA digestion products will be referred to as Eco, Bam, Sal, Kpn, Pst, and Xho.

Electrophoresis. Sizes of DNA fragments were estimated by coelectrophoresis in agarose gels with Eco-digested lambda, P22, and SPP1 DNA (Helling and Lomax, 1978). For separation of very large fragments the TEA-NaCl buffer system of Helling, Goodman, and Boyer (1974) was used with tube or horizontal slab gels (McDonell, Simon, and Studier, 1977). Routine rapid electrophoresis was carried out in horizontal gels using $0.7 \%$ agarose in tris-borate-EDTA buffer (Peacock and Dingman, 1968).

Transfer of DNA to Nitrocellulose Membranes. The DNA fragments in agarose gels were denatured and transferred to nitrocellulose membranes by the procedure of Southern (1975). The desired portion of the gel was trimmed and soaked in $1.5 \mathrm{M} \mathrm{NaCl}-0.5 \mathrm{M} \mathrm{NaOH}$ for $15 \mathrm{~min}$. The gel was rinsed with water and neutralized by immersing in $3 \mathrm{M} \mathrm{NaCl}-0.5 \mathrm{M}$ tris $\cdot \mathrm{HCl}, \mathrm{pH} 7.3$ for $15 \mathrm{~min}$. The gel was then immersed in $20 \times \mathrm{SSC}$ for $5 \mathrm{~min}$. (SSC is $0.15 \mathrm{M}$ $\mathrm{NaCl}-0.015 \mathrm{M}$ sodium citrate, $\mathrm{pH} 7.0$.) The gel was placed on two layers of filter paper wet with $20 \times$ SSC, with plastic wrap underneath. A nitrocellulose membrane (Millipore HAWP) cut to the exact dimensions of the gel, washed three times in boiling water, and soaked in $2 \times$ SSC, was carefully positioned on the gel. About 20 layers of filter paper (dry) cut to the gel dimensions were placed on top, and then a $\mathrm{cm}$ of paper toweling. A glass plate with a weight atop was placed over the toweling. The bottom layer of filter paper was soaked in $20 \times \mathrm{SSC}$, and additional $20 \times$ SSC was added as the dry paper sucked the liquid up through the gel. After $3 \mathrm{hr}$ or overnight the nitrocellulose filter was peeled from the gel after immersing in $2 \times \mathrm{SSC}$, washed in $2 \times \mathrm{SSC}$, and baked two h under vacuum at $80^{\circ} \mathrm{C}$.

Preparation of ${ }^{32} P$-labelled $R N A$. The RNA polymerase reaction mixture contained $40 \mu \mathrm{m} \mathrm{ATP}, 40 \mu \mathrm{m}$ CTP, $40 \mu \mathrm{m} \mathrm{UTP}$, and $40 \mu \mathrm{m}$ $\alpha^{32} \mathrm{P}-\mathrm{GTP}(17.5 \mu \mathrm{Ci}$; Amersham batch \#7803), $40 \mathrm{mM}$ Tris $\cdot \mathrm{HCl}$, $\mathrm{pH} 8.0,10 \mathrm{mM} \mathrm{Mg} \mathrm{Cl}, 10 \mathrm{mM}$ mercaptoethanol, $3 \mu \mathrm{g}$ of plasmid DNA and $3 \mu$ lof RNA polymerase (core enzyme) in a total volume of $100 \mu \mathrm{l}$. The reaction mixture was incubated at $37^{\circ} \mathrm{C}$ for $2 \mathrm{~h}$ and $1 \mu \mathrm{l}$ aliquots were removed for measuring total radioactivity and percent incorporation. At the end of the reaction, tRNA ( $E$. coli, $100 \mu \mathrm{g}$ ) was added as carrier and the reaction mixtures were treated with pancreatic DNase $(30 \mu \mathrm{g})$ for $10 \mathrm{~min}$ at $37^{\circ}$. The reaction mixtures were extracted with an equal volume of buffer-saturated phenol to remove protein and were chromatographed on a Sephadex G-50 column (packed in a $10 \mathrm{ml}$ serological pipet and equilibrated with $10 \times$ SSC) to remove unreacted GTP. Fractions from the void volume containing radioactivity were frozen separately. For use in the filter hybridization assay, each fraction was mixed with an equal volume of formamide to yield hybridization conditions of $5 \times \mathrm{SSC}, 50 \%$ formamide

RNA-DNA Hybridization. The dried filters containing transferred DNA fragments were soaked in the hybridization mixture containing radioactive RNA and incubated under paraffin oil at $37^{\circ}$ for $18 \mathrm{~h}$. The filters were blotted and soaked for $60 \mathrm{~min}$ in $5 \times \mathrm{SSC}$, $50 \%$ formamide at $37^{\circ}$ and three times in $2 \times \mathrm{SSC}$ at room temp. The filters were treated with $20 \mu \mathrm{g} / \mathrm{ml}$ ribonuclease A (which had been boiled $10 \mathrm{~min}$ in $0.05 \mathrm{M}$ sodium acetate, $\mathrm{pH} 5.0$ to inactivate DNase) for $60 \mathrm{~min}$ in $2 \times \mathrm{SSC}$, and washed once more in $2 \times \mathrm{SSC}$. The air dried filters were wrapped in plastic and placed between sheets of Kodak X-omat RP5 film in a cassette containing intensifying screens. The film was exposed for 1 week at $-70^{\circ}$ to visualize the bands.

Preparation and Hybridization of ${ }^{3} H$-labelled DNA. Radioactive DNA was prepared from ${ }^{3} \mathrm{H}$-thymidine triphosphate (ICN) or a mixture of two or more ${ }^{3} \mathrm{H}$-labelled nucleoside triphosphates by nick translation (Rigby et al., 1977). Dried filters containing bound denatured DNA were prepared for hybridization with radioactive DNA by coating with the Denhardt mixture plus $0.25 \%$ sodium dodecyl sulfate (Denhardt, 1966). Hybridization to DNA on the filter took place in a sealed plastic bag for two days at $37^{\circ}$ in a $4 \mathrm{ml}$ reaction mixture containing $50 \%$ formamide, $5 \times \mathrm{SSC}$, and about $0.6 \mu \mathrm{g}{ }^{3} \mathrm{H}$-labelled DNA (specific activity about $10^{6} \mathrm{cpm} / \mu \mathrm{g}$ ). Radioactivity from hybridized ${ }^{3} \mathrm{H}$-labelled DNA bound to nitrocellulose filters was visualized by layering with $10 \% 2,5$-diphenyloxazole (PPO) in toluene (Southern, 1975) and fluorography at $-70^{\circ} \mathrm{C}$, with activated film (Kodak XR-5; Lasky and Mills, 1975).

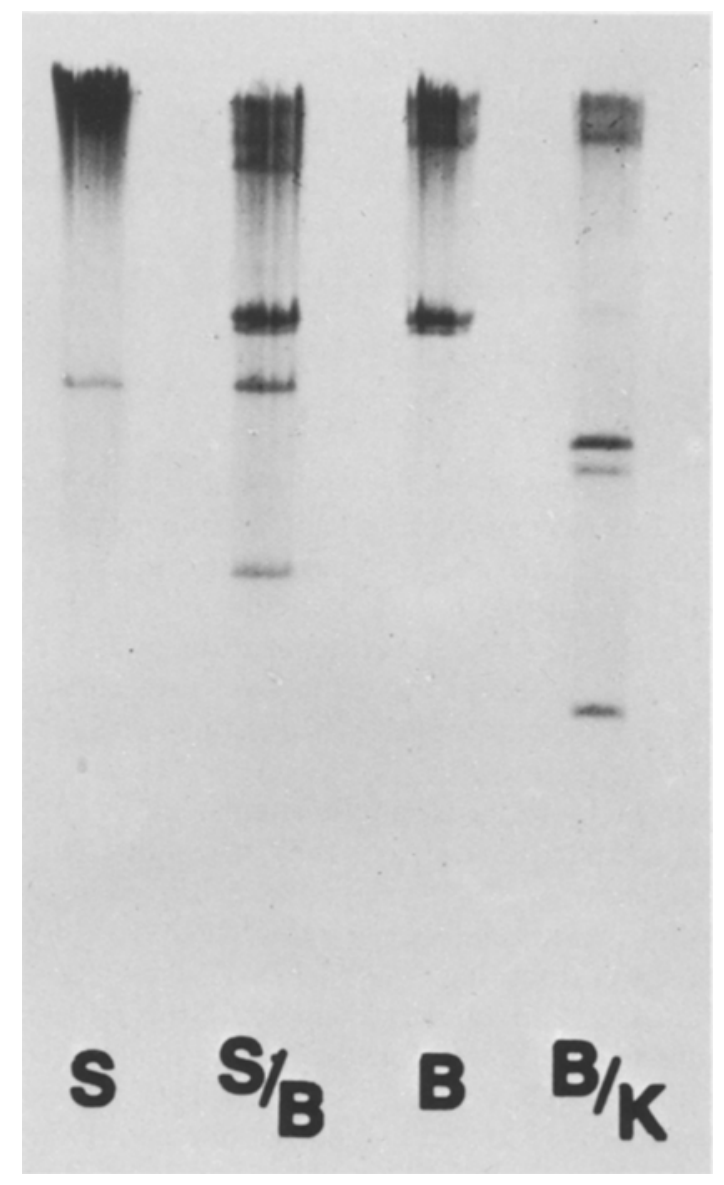

Fig. 1. Agarose gel electrophoretic pattern of restriction endonuclease-treated chloroplast DNA. Slots represent (left to right) DNA digested by $\mathrm{Sal}, \mathrm{Sal}+\mathrm{Bam}, \mathrm{Bam}$, and $\mathrm{Bam}+\mathrm{Kpn}$. Migration is from well at top toward bottom. Sample sizes and exposure time were optimal for identification of smaller fragments and larger fragments are not resolved. The well resolved fragments are of the following sizes $(\mathrm{kb}): \mathrm{S}, 4.4 ; \mathrm{S} / \mathrm{B}, 5.68(\mathrm{X} 2), 5.25,4.4,2.73$; $\mathrm{B}, 5.68$ (X2), 5.25; B/K, 3.71 (X2), 3.28, 1.97 (X3) 


\section{Results}

Defining the Origin of the Restriction Map of Chloroplast DNA. The circular Euglena chloroplast DNA molecule is cleaved by endonuclease Sal into three fragments: A, B and C. A and B are each larger than $40 \mathrm{~kb}$ while $\mathrm{Sal} \mathrm{C}$ is approximately $4.4 \mathrm{~kb}$ (Fig. 1).

The Sal C fragment was inserted at the Sal site of plasmid pBR322 to form plasmid pRBH021 (Table 1). When pRBH021 was treated with restriction endonucleases Sal and Eco, the Sal $\mathrm{C}$ segment was cleaved twice by Eco to give segments of 2.20, 1.34, and $0.86 \mathrm{~kb}$. The $1.34 \mathrm{~kb}$ segment came from the middle of the cloned Sal C fragment and co-migrated with Eco segment $\mathrm{V}$ of total chloroplast DNA (Table 2). The cloned Sal C DNA and the chloroplast DNA of a plasmid containing Eco segment $\mathrm{V}$ were found to hybridize with each other, showing that Eco fragment $\mathrm{V}$ was located within the Sal $\mathrm{C}$ segment of intact chloroplast DNA (Lomax, unpublished results).

Table 2. EcoRI fragments of chloroplast DNA

\begin{tabular}{|c|c|c|c|}
\hline Fragment & $\begin{array}{l}\text { Former } \\
\text { designation }^{a}\end{array}$ & $\operatorname{Size}(k b)^{b}$ & $\begin{array}{l}\text { rRNA } \\
\text { hybridization }\end{array}$ \\
\hline $\mathrm{A}$ & A1 & 22.3 & \\
\hline B & $\mathrm{A} 2$ & 21.5 & $+(\mathrm{R})^{\mathrm{c}}$ \\
\hline C & $\mathrm{B}$ & 9.7 & \\
\hline $\mathrm{D}$ & $\mathrm{C}$ & 9.09 & \\
\hline $\mathrm{E}$ & $\mathrm{D}$ & 7.4 & \\
\hline$F$ & $\mathrm{E}$ & 7.3 & $+(\mathrm{M})$ \\
\hline $\mathrm{G}$ & $\mathrm{F}$ & 7.0 & \\
\hline $\mathrm{H}$ & $\mathrm{G}$ & 5.3 & \\
\hline I & $\mathrm{H}$ & 4.65 & \\
\hline $\mathrm{J}$ & I1 & 3.65 & \\
\hline $\mathrm{K}$ & $\mathrm{I} 2$ & 3.65 & \\
\hline L & $\mathrm{J}$ & 3.3 & \\
\hline $\mathrm{M}$ & $\mathrm{K}$ & 3.2 & $+(\mathrm{M})$ \\
\hline $\mathrm{N}$ & L & 3.05 & \\
\hline $\mathrm{O}$ & M1 & 2.95 & $+(\mathrm{M})$ \\
\hline$P$ & M2 & 2.95 & \\
\hline$Q$ & $\mathrm{~N}$ & 2.57 & \\
\hline $\mathbf{R}$ & $\mathrm{O}$ & 2.48 & $+(\mathrm{R})$ \\
\hline $\mathrm{S}$ & $\mathrm{P}$ & 2.30 & $+(\mathrm{R})$ \\
\hline $\mathrm{T}$ & $\mathrm{Q}$ & 1.77 & \\
\hline $\mathrm{U}$ & $\mathrm{R}$ & 1.69 & \\
\hline V & $\mathrm{S}$ & 1.34 & \\
\hline W & $\mathrm{T}$ & 1.12 & \\
\hline$X$ & U1 & 1.11 & \\
\hline$Y$ & $\mathrm{U} 2$ & 1.11 & \\
\hline Z & $\mathrm{V}$ & 0.95 & \\
\hline $2 \mathrm{~A}$ & W1 & 0.92 & \\
\hline $2 \mathrm{~B}$ & W2 & 0.92 & \\
\hline $2 \mathrm{C}$ & $\mathrm{X}$ & 0.87 & \\
\hline
\end{tabular}

a Lomax et al. (1977)

b Mielenz et al. (1977) have reported similar molecular weights - (R) indicates homology with Eco R, (M) indicates homology with Eco M

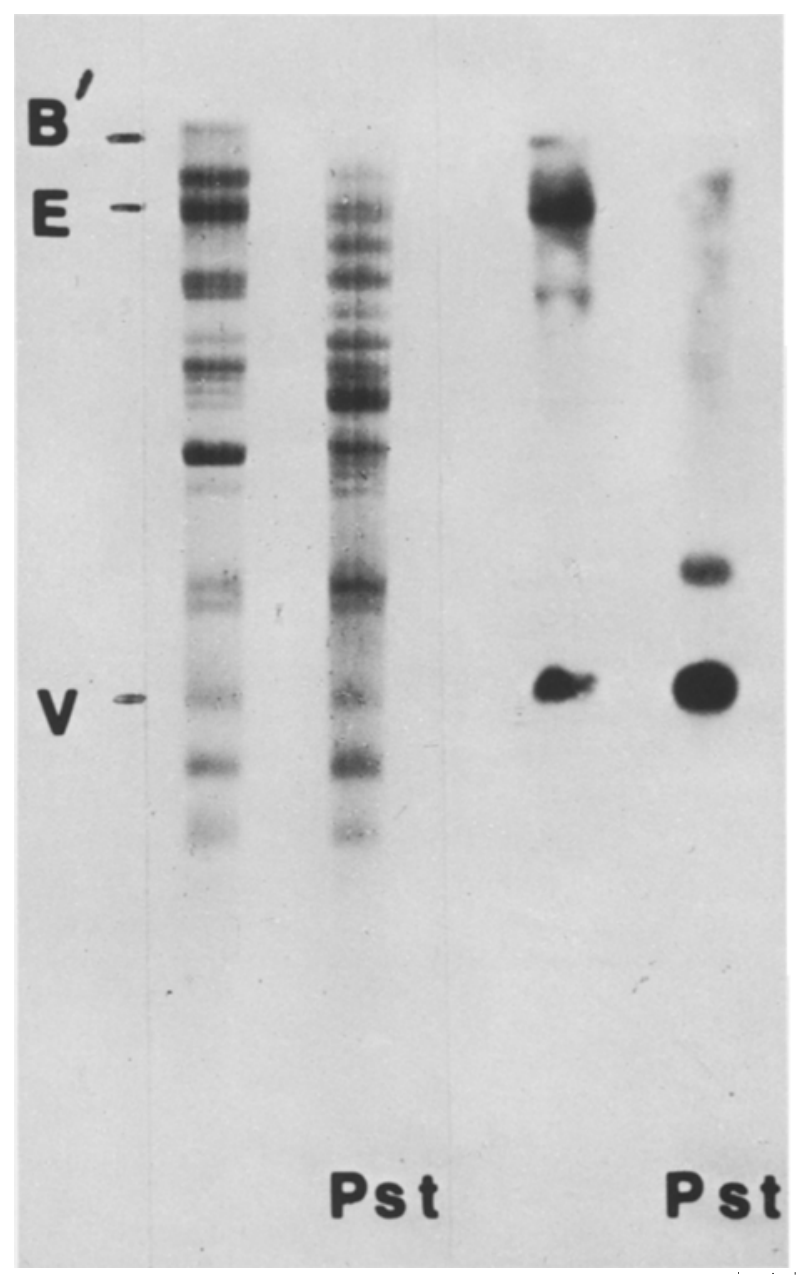

Fig. 2. Hybridization of Sal C DNA to Eco and Eco + Pst digested chloroplast DNA. From left, the patterns represent 1) the electrophoretic separation of Eco + Bam digested DNA; 2) the electrophoretic separation of DNA digested by Eco+Pst; 3) and 4), the corresponding fluorograms after transfer to a nitrocellulose membrane and hybridization with ${ }^{3} \mathrm{H}-\mathrm{pRBHO} 21$ (Sal C) DNA. Bam does not cleave Eco $V$ or Eco $E$, but cleaves $3.2 \mathrm{~kb}$ from the end of Eco B distal to the Sal C region. Bam digestion helped clarify the hybridization pattern. Fluorograms were overexposed to reveal bands with small amounts of hybridization. Partial degradation of the largest fragments and some nonspecific hybridization may be observed

${ }^{3} \mathrm{H}$-labelled pRBH021 DNA (containing the Sal C fragment) was also found to hybridize with Eco $\mathrm{V}$ in Eco-digested total chloroplast DNA (Fig. 2). The complete electrophoretic pattern of Eco-digested chloroplast DNA is labelled in Fig. 3 for comparison. In addition to Eco V, Eco $B$ and Eco $E$ also hybridized with pRBH021 DNA, showing that Eco V is flanked by these two Eco segments in chloroplast DNA. The observation that the Eco B and Eco E bands disappear after treatment of Chl DNA with both Eco and Sal (and therefore must contain two of the three Sal sites) is consistent with this interpreta- 


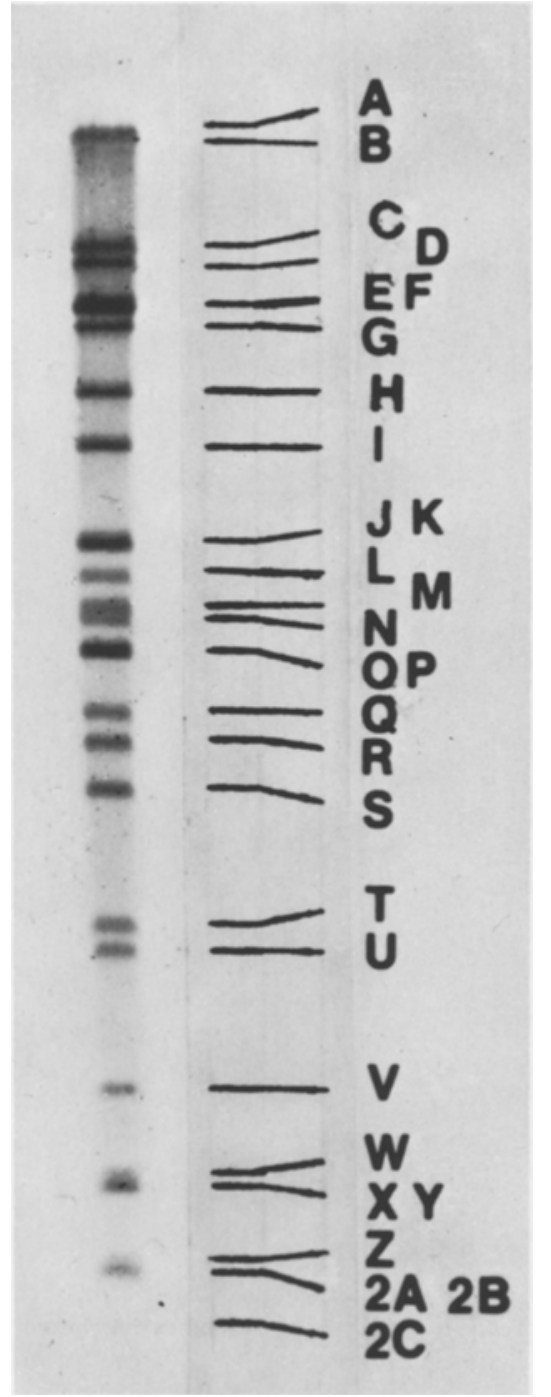

Fig. 3. Agarose gel electrophoretic pattern of Eco-digested chloroplast DNA

tion (not shown). We have been unable to identify the third Eco segment containing a Sal cleavage site from the double-digest gel pattern.

The following experiment showed that the $2.20 \mathrm{~kb}$ portion of Sal $\mathrm{C}$ is shared with Eco $\mathrm{B}$, while the $0.86 \mathrm{~kb}$ portion is shared with Eco E. Eco E is cleaved by Pst (Fig. 2) whereas Sal C is not (not shown). After transferring chloroplast DNA digested by both Eco and Pst to a nitrocellulose membrane, ${ }^{3} \mathrm{H}-\mathrm{Sal}$ C DNA was found to hybridize with the band containing fragment Eco V, as expected (Fig. 2). No hybridization was observed at the position corresponding to Eco $E$ because that fragment had been cleaved by Pst. Instead, hybridization to a new band corresponding to DNA of $1.81 \mathrm{~kb}$ was observed (Fig. 2). The new band must contain $0.86 \mathrm{~kb}$ from Sal C and

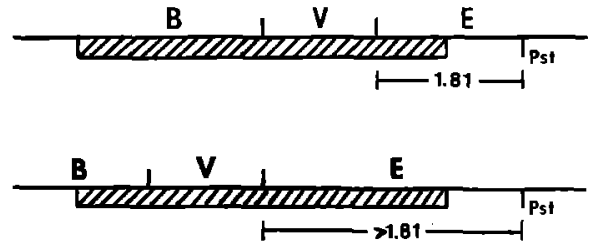

Fig. 4. Location of Sal sites in Eco B and Eco E. Boxed section designates Sal $\mathrm{C}$ segment. The $2.20 \mathrm{~kb}$ DNA fragment released from Sal $\mathrm{C}$ by Eco digestion must be part of Eco B (as shown above) and not part of Eco E (as shown below) because cleavage of Eco E by Pst releases a $1.81 \mathrm{~kb}$ piece which hybridizes with Sal C DNA

an additional $0.95 \mathrm{~kb}$ from that portion of Eco $\mathrm{E}$ which falls between the Sal and Pst sites (Fig. 4). A band containing DNA of $5.59 \mathrm{~kb}$ and corresponding to the remainder of Eco $\mathrm{E}$ was visualized by ethidium bromide staining (Fig. 2).

With this information we define the circular chloroplast DNA map as extending from the Sal site in Eco B (zero coordinate) across Eco V, Eco E and the remainder of $138 \mathrm{~kb}$ circular DNA (Fig. 4, 14).

The Location and Arrangement of Ribosomal RNA Genes. Eco fragments B, F, M, O, R and $\mathrm{S}$ have been shown to hybridize with chloroplast rRNA (Lomax et al., 1977; Mielenz, Milner and Hershberger, 1977). Rawson et al., (1978) found that three sets of rRNA genes (rDNA) are clustered on the cloroplast genome of $E$. gracilis $Z$. If $E$. gracilis bacillaris also has three adjacent sets of rRNA genes, the six hybridizing Eco fragments must map in consecutive order. Furthermore fragments $\mathrm{B}$ and $\mathrm{F}$ are expected to define the outer limits of this region because of their large size relative to the size of three rDNA repeats. The following experiments confirm these predictions and provide an unambiguous fragment order.

${ }^{32}$ P-labelled RNA was made from plasmids pMIL12 (containing Eco R) and pMIL19 (containing Eco M). The radioactive RNA was hybridized with Eco-generated DNA fragments from plasmids pMIL12, pMIL17 and pMIL19 after electrophoretic separation on an agarose gel. As shown in Fig. 5 (gel slot 3) RNA from pMIL19 hybridized with both the slower moving DNA band (the pSF2124 vector) and the faster Eco $\mathrm{M}$ band of DNA from pMIL19 itself. pMIL19 RNA did not hybridize with DNA from Eco R (gel slot 1) or Eco S (gel slot 2) showing that Eco $\mathrm{M}$ shares no homology with these fragments even though all three chloroplast DNA fragments hybridize with rRNA.

RNA from pMIL12 hybridized with Eco R (slot 1) and failed to hybridize with Eco $M$ (slot 3), as expected. However it also hybridized with Eco $\mathrm{S}$ (slot 2). Therefore Eco R and Eco S are homologous 


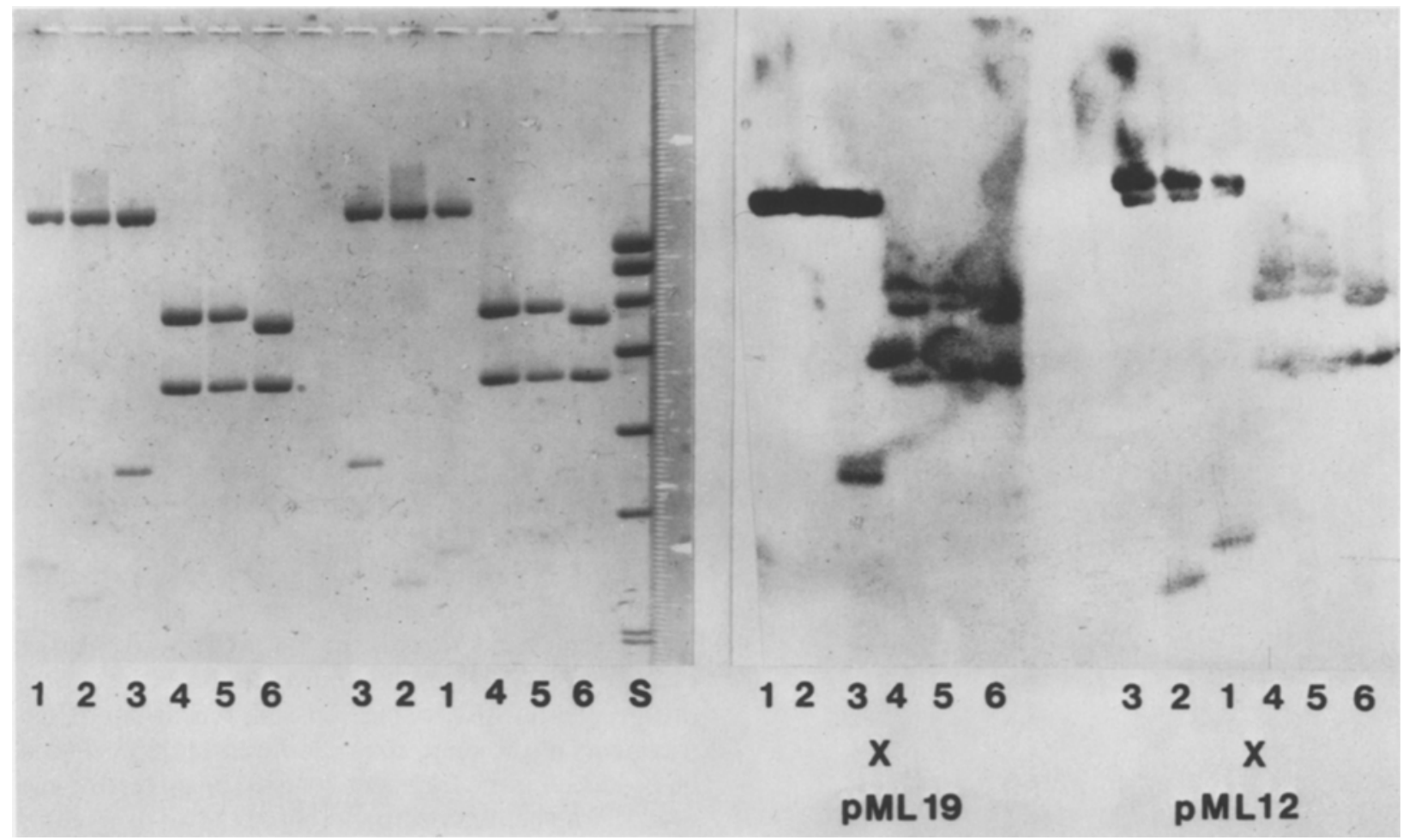

Fig. 5. Hybridization of ${ }^{32}$ P-RNA made from pMIL19 and pMIL12 with cloned fragments of chloroplast DNA. Left: agarose gel electrophoretic patterns. Right: corresponding radioautogram after transfer to a nitrocellulose membrane and hybridization with RNA from the plasmid specified. 1, Eco-digested pMIL12 DNA;2, Eco-digested pMIL17 DNA; 3, Eco-digested pMIL19 DNA; 4, Bam-digested pRBHO23 DNA; 5, Bam-digested pRBHO26 DNA; 6, Bam-digested pRBHO22 DNA; S, Eco-digested phage SPPI DNA. Size of the pBR322 cloning vector is $4.3 \mathrm{~kb}$; size of RSF2124 is $11.3 \mathrm{~kb}$. Radioautograms were overexposed in order to reveal even small amounts of hybridization. The film was moved slightly during exposure, resulting in several apparent double bands on the radioautograms

and presumably represent equivalent regions of two rDNA repeats, although they differ slightly in size.

Further experiments, in which plasmid DNA from pMIL12 and pMIL19 were hybridized (separately) to the Eco fragments of total chloroplast DNA, identified two classes of fragments that are homologous: one containing Eco F, M and $\mathrm{O}$; the other, B, R, and S (Fig. 6).

Mapping the rDNA repeat regions was facilitated by cloning the corresponding Bam fragments from this region. Cleavage of chloroplast DNA by Bam releases three fragments (Bam D, E and F) approximately the size expected for one rDNA repeat segment (Fig. 1). Bam D and Bam E are each $5.68 \mathrm{~kb}$ and $\mathrm{Bam} F$ is $5.25 \mathrm{~kb}$ in size. Bam $\mathrm{E}$ and Bam $\mathrm{F}$ were cloned in pBR322, shown to contain rDNA, and their structures were examined using restriction endonucleases.

Bam E (in pRBHO23 and pRBHO26) and Bam $F$ (in pRBHO22) each hybridized with RNA made from Eco R DNA (pMIL12) and from Eco M DNA (pMIL19) (Fig. 5, slots 4-6).

The structures of the cloned Bam E and Bam $F$ fragments, and of Eco $M$ were determined by diges- tion with the enzymes Eco, Bam, Kpn and Xho. The results are depicted in Fig. 7. The fragments have been aligned to give a consistent order. Bam $F$ is cleaved twice by Eco, releasing an internal fragment which co-migrates with Eco $\mathrm{S}$ in gel electrophoresis, and hybridizes with RNA made from Eco R DNA. The remainder of Bam $F$ does not hybridize with Eco R - RNA (not shown). Bam E contains a single Eco site located the same distance from a Bam terminus as one of the Eco sites in Bam F. Only the $3.23 \mathrm{~kb}$ segment resulting from Eco treatment of Bam E hybridizes with RNA from Eco R (not shown). Eco $M$ contains an internal Bam site located the same distance from an Eco terminus.

Inspection of Fig. 7 reveals that all three fragments have the same relative locations of restriction sites in the regions corresponding to the left half of the Bam fragments. In addition, an Xho site is located approximately $0.33 \mathrm{~kb}$ to the left of the right Bam terminus of the Bam fragments, and about $0.33 \mathrm{~kb}$ left of the internal Bam site of Eco M.

The results suggest that each of the three Bam segments contains the information for a single rDNA repeat. That portion of each Bam segment which is 
homologous to Eco $\mathrm{B}, \mathrm{R}$, and $\mathrm{S}$ is in the right arm as diagrammed, and the remainder is homologous to Eco fragments, F, M, and $\mathrm{O}$. The structures of Bam $\mathrm{E}$ and Bam F, and the postulated structure of Bam D (which must contain Eco R) are shown in Fig. 8.

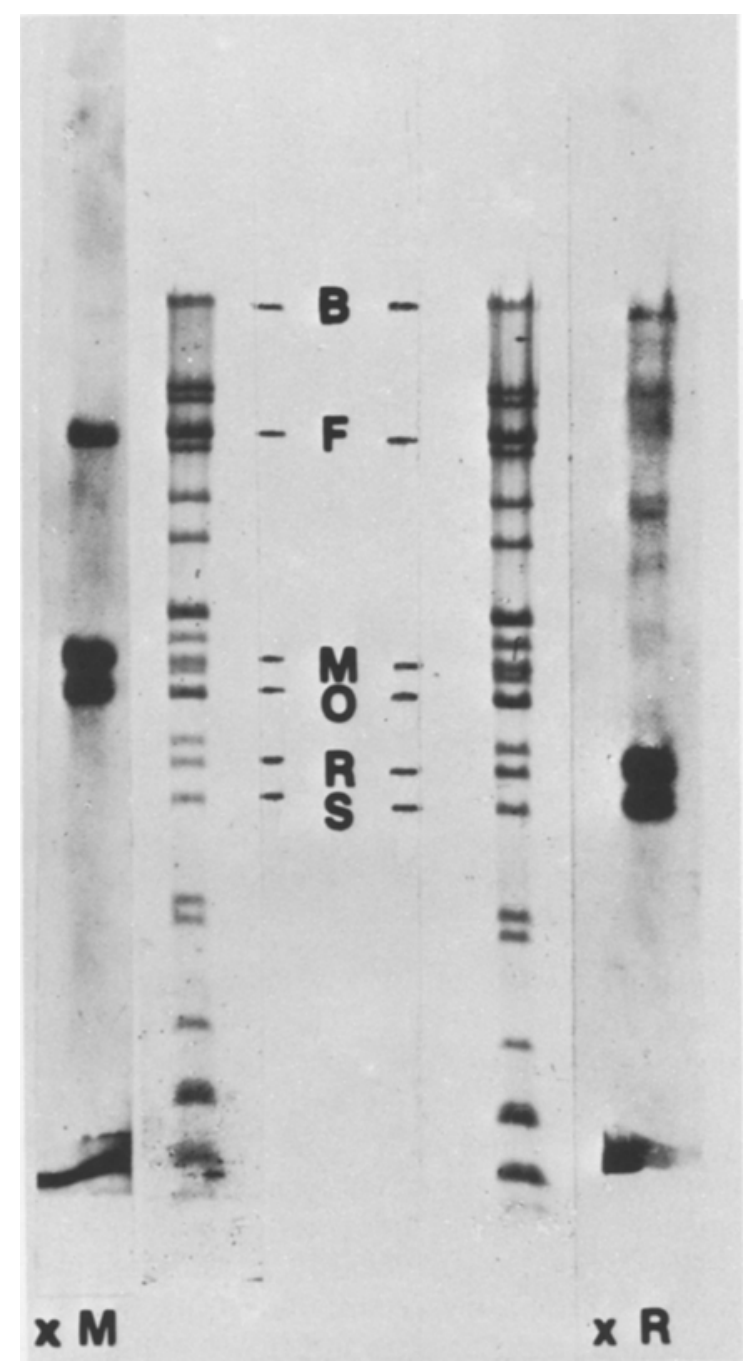

Fig. 6. Homology of repeated segments of the rRNA genes. Middle slots show separation of Eco fragments of chloroplast DNA after agarose gel electrophoresis. Outside are the corresponding fluorograms after transfer to a nitrocellulose membrane and hybridization with ${ }^{3} \mathrm{H}$-pMIL19 DNA (containing Eco M), left, and ${ }^{3} \mathrm{H}-\mathrm{pMIL} 12$ DNA (containing Eco $\mathrm{R}$ ), right
Bam E must overlap with Eco B because Bam $\mathrm{E}$ has only a single Eco cleavage site and therefore contains neither Eco R nor Eco S (which are homologous with the rDNA portion of Eco B). The order of fragments, then, must be

a) Bam D - Bam F - Bam E - remainder of Eco B

or B.

b) Bam F - Bam D- Bam E - remainder of Eco

The addition of the segments between Eco sites in adjoining Bam fragments should give fragments of the sizes of Eco $\mathrm{M}$ and Eco O. This prediction is verified if we align the fragments in either order.

The following experiments show that order a) is correct (Fig. 9). If Kpn cleaves each rDNA repeat once, at the positions shown in Figure 9, two fragments, one $5.68 \mathrm{~kb}$ and the other $5.25 \mathrm{~kb}$ in length, will be generated regardless of whether order a) or b) is correct. The results shown in Fig. 10 confirm this prediction. If Xho cleaves each repeat once, two fragments of the same sizes produced by Kpn should be produced if the fragment order a) is correct. However if fragment order b) is correct, two fragments each of $5.68 \mathrm{~kb}$ would be produced by Xho. The results (Fig. 10) are in accord with order a) and rule out order b). The correct map is shown in Fig. 11.

The following observations lend support to the proposed map. Xho cleaves the same size piece $(0.33 \mathrm{~kb})$ from Bam D, E, and F fragments of chloroplast DNA (Fig. 12). Kpn cleaves a $1.97 \mathrm{~kb}$ segment from each of the same three Bam fragments (Fig. 1). The larger products of $\mathrm{Kpn}$ and Xho cleavage of the rDNA fragments homologous to Eco R (Eco B, $\mathrm{R}$, and $\mathrm{S}$ ) and of the rDNA fragments homologous to Eco $M$ (Eco $F, M$, and $O$ ) were identified by hybridization and found to be consistent with those expected from the map (Fig. 13). The Eco R and $\mathrm{S}$ segments were not cut by either Xho or Kpn. Eco $\mathrm{B}$ is cleaved by Xho to generate a $2.9 \mathrm{~kb}$ fragment hybridizing with Eco R. Eco $F$ is cleaved by Kpn to yield a slightly smaller fragment (about $6.8 \mathrm{~kb}$ ) hybridizing with Eco M. (Fragments smaller than about $0.8 \mathrm{~kb}$ have run off this gel and so could not be seen). Eco M and Eco O likewise are cleaved by $\mathrm{Kpn}$ to yield segments of $2.7 \mathrm{~kb}$ and $2.45 \mathrm{~kb}$ respec-

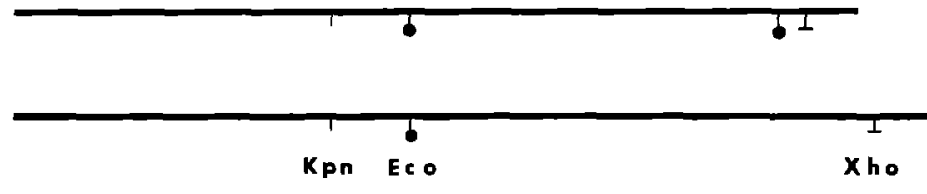

E $c \circ M$

Fig. 7. Structures of three cloned

B om F segments of the chloroplast rDNA. The segments are aligned so that the overlapping portions of the Eco and

Bam E Bam fragments appear to be identical (i.e., Bam site- Kpn site-Eco site) 

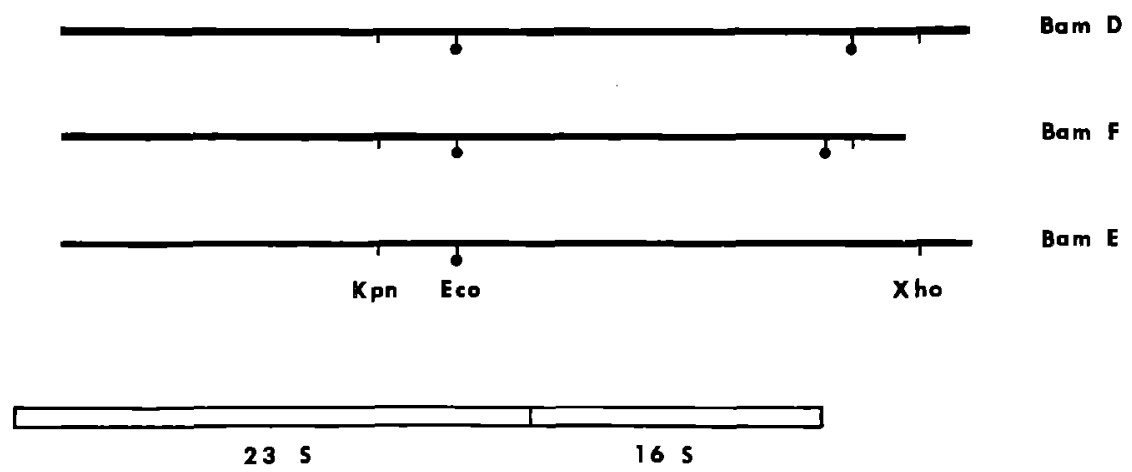

Fig. 8. Structures of the three Bam segments of rDNA

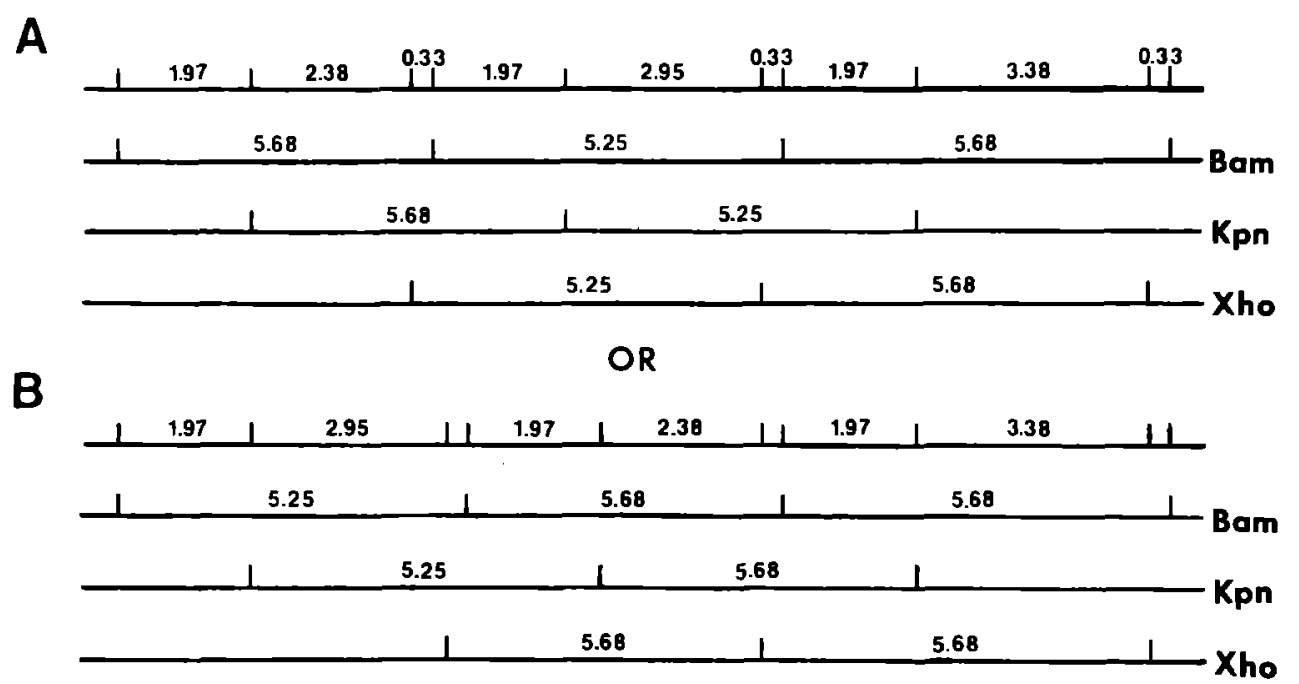

Fig. 9. Postulated alternative structures for the segment of chloroplast DNA containing repeated rRNA genes. Sizes in kb are given

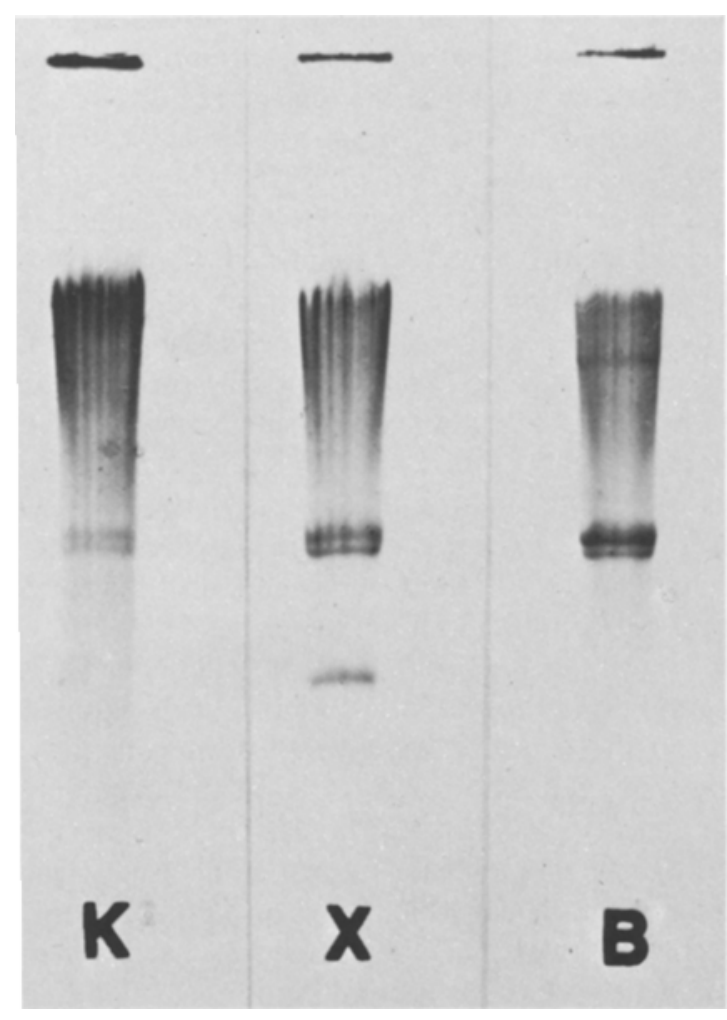

tively. Xho does not cut Eco F, but produces $2.8 \mathrm{~kb}$ derivatives from both Eco $\mathrm{M}$ and Eco $\mathrm{O}$.

\section{Discussion}

We have derived an unambiguous order for eight of the 29 Eco-generated chloroplast DNA fragments, comprising over $35 \%$ of the total genome (Fig. 14). This region encompasses the rRNA genes, but not the tRNA genes (unpublished results). The map shows that three sets of rRNA genes are sequential and have the same orientation, just as in E. gracilis $Z$ (Rawson et al., 1978; Gray and Hallick, 1978; Knopf and Stutz, 1978).

The organization of the chloroplast genome in Euglena is strikingly different from that of the chloroplast DNA of the green alga Chlamydomonas rein-

Fig. 10. Agarose gel electrophoretic separation of restriction endonuclease-treated chloroplast DNA. Slots show (left to right) separation of DNA digested by $K_{p n}$, Xho, and Bam. Note that all three enzymes produce fragments of 5.68 and $5.25 \mathrm{~kb}$, but the intensity of the 5.68 band after Bam digestion is relatively greater, because it contains two fragments 


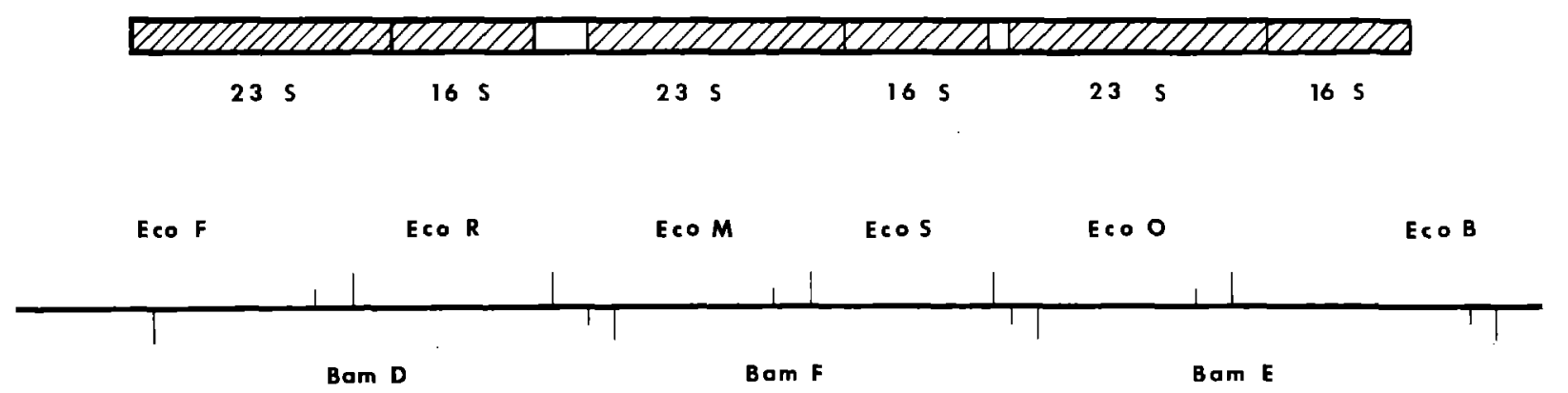

Fig. 11. Map of restriction sites in the rDNA region of E. gracilis bacillaris chloroplast DNA. Short vertical lines above the map represent Kpn sites; below the map, Xho sites. The presumptive location of the 16S and 23S RNA coding regions is shown

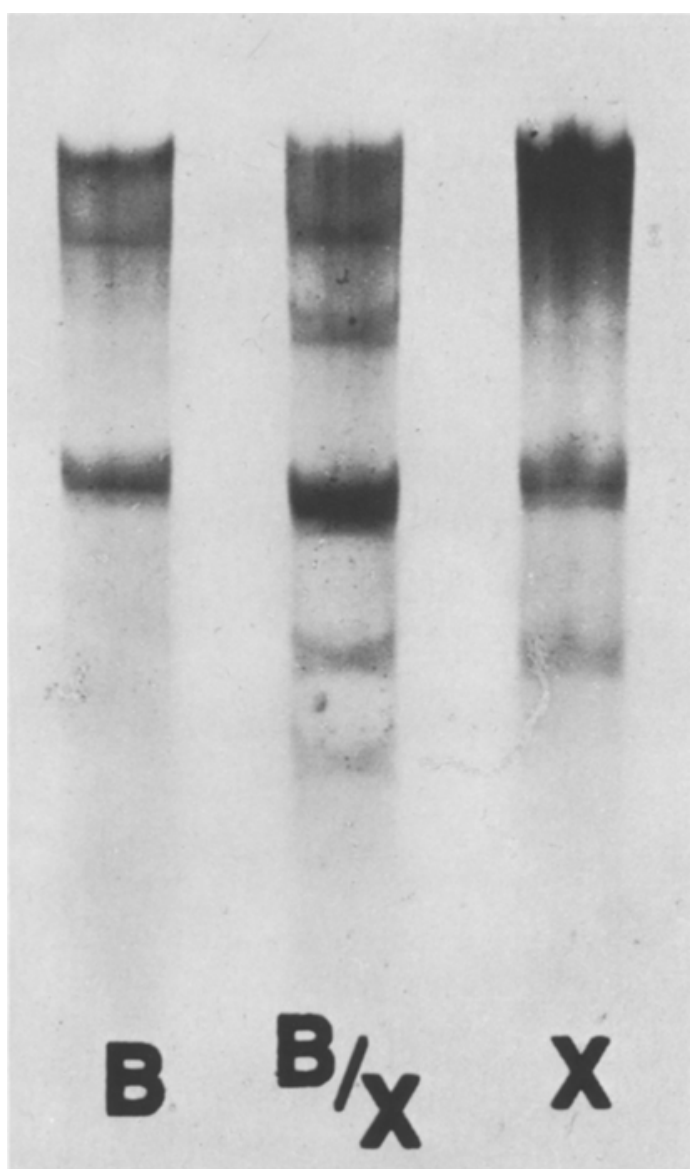

Fig. 12. Agarose gel electrophoretic patterns of endonucleasetreated chloroplast DNA. Slots show (left to right) DNA digested by Bam, Bam + Xho, and Xho

hardi (Rochaix and Malnoe, 1978) maize (Bedbrook, Kolodner, and Bogorad, 1977), and spinach (Whitfeld, Herrmann and Bottomley, 1978). In all those organisms two copies of the rDNA appear in inverted repeats and are separated by a substantial segment of the chloroplast DNA.

A detailed comparison reveals differences between the two Euglena strains. Strain $Z$ has three identical, tandemly repeated rRNA genes. Strain bacillaris on the other hand has three tandemly repeated rRNA genes which appear to be identical over most of the individual repeat length, but differ both in length and in sequence at the ends closer to the distal end of the chromosome. We can align the repeat sequences from the two strains for comparison because the repeats are bracketed by essentially the same two Eco fragments ( $\mathrm{F}$ and $\mathrm{B})$, and they are located at about the same distance from a $4.4 \mathrm{~kb}$ Sal $\mathrm{C}$ fragment. When we do so we find that the rDNA repeats in the two strains differ only at the positions where the internal bacillaris repeats differ. (We assume the $16 \mathrm{~S}-23 \mathrm{~S}$ rDNA orientation of the two strains is the same (Rawson et al., 1978) and have drawn our figures accordingly.) These regions of difference are almost certainly the "spacers" initiating and separating repeats but not transcribed into rRNA. Similar heterogeneity has been found in the spacer regions of repeated sequences in other organisms (e.g. Wellauer et al., 1976; Carroll and Brown, 1976).

In $E$. gracilis $Z$ precursor rRNA molecules of $1.88 \mathrm{~kb}$ and $3.41 \mathrm{~kb}$ have been identified (Scott, 1976). With transcripts this large, the nontranscribed spacer regions of strain bacillaris could be no more than $0.39 \mathrm{~kb}$ in two repeats and essentially zero in the third. The strain $Z$ spacer would be no more than $0.31 \mathrm{~kb}$ (Gray and Hallick, 1978; Knopf and Stutz, 1978). Rawson's estimates of the sizes of the rRNAs and of the rDNA repeat unit are slightly smaller (Rawson et al., 1978), allowing spacers up to $0.48 \mathrm{~kb}$ in $Z$, and 0.68 and $0.25 \mathrm{~kb}$ in bacillaris.

The spacer located in Eco B of strain bacillaris has lost an Eco site found in $Z$ and also at the equivalent site in the other bacillaris rDNA repeats. It is puzzling that each Xho site (located at the beginning of each repeat) is about $0.33 \mathrm{~kb}$ left of a Bam site (located at the end of each repeat and also at the beginning of the repeat which lacks an Eco site). Possibly a short part of a rDNA repeat has been joined to the first full repeat by recombination, thus adding 


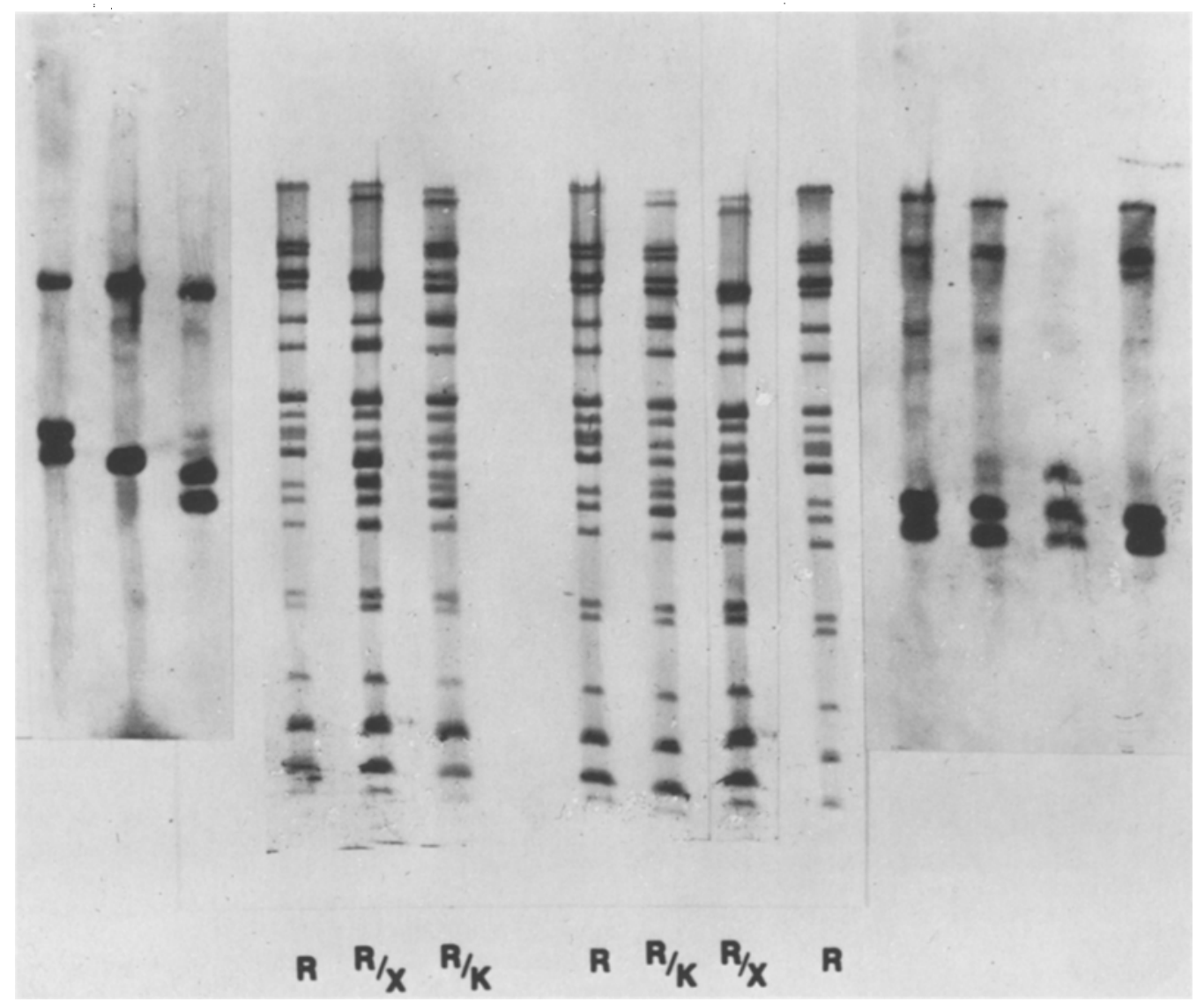

Fig. 13. Cleavage of Eco fragments of chloroplast rDNA by Kpn and Xho. Middle: agarose gel electrophoretic patterns of DNA digested by Eco (R), Eco + Xho, and Eco +Kpn. The Eco + Xho gel pattern shown at right is the same as the one at left. The actual Eco + Xho pattern was too faint to see well in the final figure. The true fragment separation differed slightly from that in the superimposed figure as can be seen by comparison with bands in the adjacent wells. The figure has been aligned properly in the region of hybridization. Corresponding fluorograms are shown after hybridization with (left) ${ }^{3} \mathrm{H}-\mathrm{pMIL} 19$ (Eco M) DNA or (right) ${ }^{3} \mathrm{H}-\mathrm{pMIL12}$ (Eco R) DNA. Fluorograms were overexposed in order to reveal even small amounts of hybridization

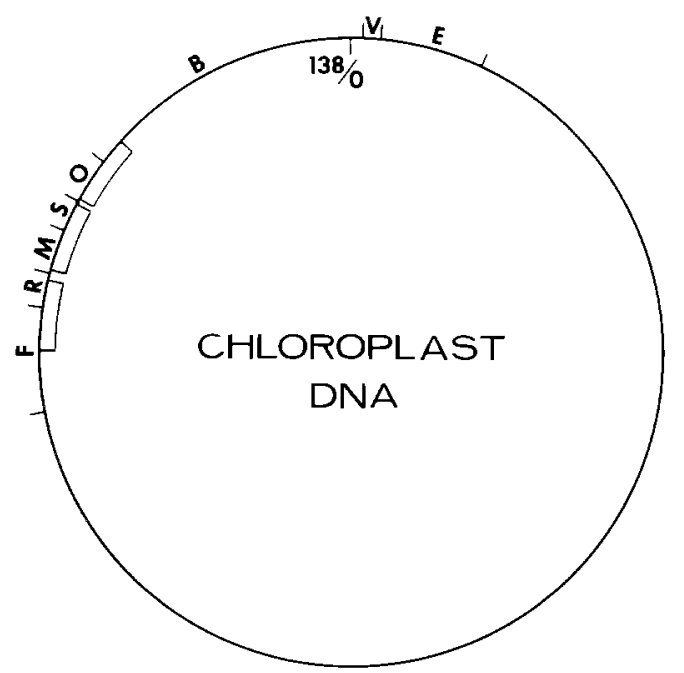

Fig. 14. Order of Eco fragments of chloroplast DNA and location of repeated rRNA genes an additional Bam site. Alternatively it may simply reflect deletion of material found in $Z$ between the first rDNA repeat and the preceeding Bam site.

These results are fully consistent and explain apparent discrepancies in the literature. Hybridization of rRNA to the large Eco B fragment in bacillaris (Lomax et al., 1977; Mielenz, Milner and Hershberger, 1977) is not inconsistent with the $Z$ map, because the bacillaris map differs in that region. These results show also that the minor differences in agarose gel electrophoretic patterns of chloroplast DNA observed in different laboratories reflect the E. gracilis strain used. It is clear that the strain used by Mielenz et al., (1977) is strain bacillaris rather than $Z$ (as reported) because the Eco fragmentation pattern and the rRNA hybridization pattern are identical with ours and discordant with Rawson et al. (1978), Gray and Hallick (1978), and Knopf and Stutz (1978) who use strain $Z$. 
Acknowledgement. We thank P. Reddy, P. Smythe, H.B. Clarke, and T. Kinney for their help. M.L. thanks J. Lederberg for generously providing facilities and support during a part of this work. Supported by NIH grant GM25565 to R.B.H., by funds from NIH Biomedical Support Grant RR-07055 and from the University of Nebraska Research Council to S.D.S., by the U.S. Energy Research and Development Administration under contract with Union Carbide Corporation, and by a Unesco fellowship and A.I.D. fellowhip to M.R. E-G. M. R. E-G. is on leave from the Department of Genetics, Cairo University.

\section{References}

Adams, J., Kinney, T., Thompson, S., Rubin, L., Helling, R.B.: Frequency-dependent selection for plasmid-containing cells of Escherichia coli. Genetics 91, (1979)

Bedbrook, J.R., Kolodner, R., Bogarad, L. : Zea mays chloroplast ribosomal RNA genes are part of a 22000 base pair inverted repeat. Cell 11, 739-749 (1977)

Carroll, D., Brown, D.D.: Adjacent repeating units of Xenopus laevis 5S DNA can be heterogeneous in length. Cell 7, 477-486 (1976)

Denhardt, D.T.: A membrane-filter technique for the detection of complementary DNA. Biochem. Biophys. Res. Commun. 23, 641-646 (1966)

Gray, P.W., Hallick, R.B.: Physical mapping of the Euglena gracilis chloroplast DNA and ribosomal RNA gene region. Biochemistry 17, 284-289 (1978)

Gray, P.W., Hallick, R.B.: Restriction endonuclease map of Euglena gracilis chloroplast DNA. Biochemistry 16, 1665-1671 (1977)

Gruol, D.J., Haselkorn, R.: Counting the genes for stable RNA in the nucleus and chloroplasts of Euglena. Biochim. Biophys. Acta 447, 82-95 (1976)

Helling, R.B., Goodman, H.M., Boyer, H.W.: Analysis of endonuclease R.EcoRI fragments of DNA from lambdoid bacteriophage and other viruses by agarose-gel electrophoresis. J. Virol. 14, 1235-1244 (1974)

Helling, R.B., Lomax, M.I.: The molecular cloning of genes general procedures. In: Genetic engineering (A. Chakrabarty, ed.). W. Palm Beach: CRC Press 1978

Knopf, V.C., Stutz, E.: Molecular cloning of the gene region coding for the chloroplast rRNA of Euglena gracilis. Mol. Gen. Genet. 163, 1-6 (1978)

Laskey, R.A., Mills, A.D.: Quantitative film detection of ${ }^{3} \mathrm{H}$ and ${ }^{14} \mathrm{C}$ in polyacrylamide gels by fluorography. J. Biochem. 56, 335-341 (1975)

Lomax, M.I., Helling, R.B., Hecker, L.I., Schwartzbach, S.D., Barnett, W.E. : Cloned ribosomal RNA genes from chloroplasts of Euglena gracilis. Science 196, 202-205 (1977)
Manning, J.E., Richards, O.C.: Isolation and molecular weight of circular chloroplast DNA from Euglena gracilis. Biochim. Biophys. Acta 259, 285-296 (1972)

McCrea, J.M., Hershberger, C.L.: Chloroplast DNA codes for transfer RNA. Nucleic Acids Res. 3, 2005-2018 (1976)

McDonell, M.W., Simon, M.N., Studier, F.W. : Analysis of restriction fragments of T7 DNA and determination of molecular weights by electrophoresis in neutral and alkaline gels. J. Mol. Biol. 110, 119-146 (1977)

Mielenz, J.R., Milner, J.J., Hershberger, C.L. : Analysis of Euglena gracilis chloroplast deoxyribonucleic acid with a restriction endonuclease, EcoRI. J. Bacteriol. 130, 860-868 (1977)

Peacock, A.C., Dingman, C.W.: Molecular weight estimation and separation of ribonucleic acid by electrophoresis in agaroseacrylamide composite gels. Biochemistry 7, 668-674 (1968)

Rawson, J.R.A., Boerma, C.L.: A measurement of the fraction of chloroplast DNA transcribed during chloroplast development in Euglena gracilis. Biochemistry 15, 588-592 (1976)

Rawson, J.R.Y., Kushner, S.R., Vapnek, D., Alton, N.K., Boerma, C.L.: Chloroplast ribosomaI RNA genes in Euglena gracilis exist as three clustered tandem repeats. Gene 3, 191-209 (1978)

Rigby, P.W.J., Dieckmann, M., Rhodes, C., Berg, P.: Labelling deoxyribonucleic acid to high specific activity in vitro by nick translation with DNA polymerase I. J. Mol. Biol. 113, 237-251 (1977)

Rochaix, J.D., Malnoe, P.: Anatomy of the chloroplast ribosomal DNA of Chlamydomonas reinhardii. Cell 15, 661-670 (1978)

Schwartzbach, S.D., Hecker, L.I., Barnett, W.E.: Transcriptional origin of Euglena chloroplast tRNAs. Proc. Natl. Acad. Sci. U.S.A. 73, 1984-1988 (1976)

Scott, N.S. : Precursors of chloroplast ribosomal RNA in Euglena gracilis. Phytochemistry 15, 1207-1213 (1976)

Slavick, N.S., Hershberger, C.L.: The kinetic complexity of $\mathrm{Eu}$ glena gracilis chloroplast DNA. FEBS Lett. 52, 171-174 (1975)

Southern, E.M.: Detection of specific sequences among DNA fragments separated by gel electrophoresis. J. Mol. Biol. 98, 503-517 (1975)

Wellauer, P.K., Dawid, I.B., Brown, D.D., Reeder, R.H.: The molecular basis for length heterogeneity in ribosomal DNA from Xenopus laevis. J. Mol. Biol. 105, 461-486 (1976)

Whitfield, P.R., Herrmann, R.G., Bottomley, W.: Mapping of the ribosomal RNA genes on spinach chloroplast DNA. Nucleic Acids Res. 5, 1741-1751 (1978)

Communicated by H. Boyer

Received February 26, 1979 